\title{
Correction to: An application of importance-performance analysis to students' evaluation of teaching
}

\section{Magdalena Cladera ${ }^{1}$}

Published online: 18 February 2022

(c) Springer Nature B.V. 2022

\section{Educational Assessment, Evaluation and Accountability (2020) 33:701-715 https://doi.org/10.1007/s11092-020-09338-4}

The original version of this article unfortunately contained a mistake. The in-text citation "Author (2020)" should be changed to "Cladera (2020)". Complete bibliographic information is available at the Reference section.

Publisher's note Springer Nature remains neutral with regard to jurisdictional claims in published maps and institutional affiliations.

The original article can be found online at https://doi.org/10.1007/s11092-020-09338-4.

\section{Magdalena Cladera}

1 Department of Applied Economics, University of the Balearic Islands, Palma de Mallorca, Spain 